Table 8. Efficiency of food utilization in suckling pigs

(Unpublished data of Barber, Braude \& Mitchell)

$\begin{array}{cccc}\begin{array}{c}\text { Age of pig } \\ \text { (days) }\end{array} & \begin{array}{c}\text { Milk } \\ (\mathrm{g})\end{array} & \begin{array}{c}\text { Meal } \\ (\mathrm{g})\end{array} & \begin{array}{c}\text { Consumption/g live-weight } \\ \text { main } \\ \text { matter } \\ (\mathrm{g})\end{array} \\ 0-7 & 3.78 & - & 0.76 \\ 8-\mathrm{I} 4 & 4.0 \mathrm{I} & - & 0.80 \\ 15-2 \mathrm{I} & 4.30 & - & 0.86 \\ 22-28 & 5.07 & 0.15 & \mathrm{I} \cdot \mathrm{I} 5 \\ 29-35 & 4.84 & 0.14 & \mathrm{I} \cdot 09 \\ 36-42 & 3.96 & 0.38 & \mathrm{I} \cdot 13 \\ 43-49 & 3.46 & 0.63 & \mathrm{I} \cdot 25 \\ 50-56 & 1.87 & 0.84 & \mathrm{I} \cdot \mathrm{II}\end{array}$

litters (thirty-one pigs) only, they show an interesting trend. There is very great need for factual evidence on efficiency of food conversion in baby pigs, gestating, lactating and empty sows, and I hope it will not be long before such evidence is forthcoming.

\title{
REFERENCES
}

Barber, R. S., Braude, R. \& Mitchell, K. G. (I955). F. agric. Sci. (In the Press.)

Betts, A. O. (1954). Private communication.

Crampton, E. W., Ashton, G. C. \& Lloyd, L. E. (1954). F. Anim. Sci. 13, 327.

Dunlop, G. \& West, A. (1942). Emp. F. exp. Agric. 10, I6r.

Ellis, N. R. \& Zeller, J. H. (1935). Tech. Bull. U.S. Dep. Agric. no. 4I3.

Gregory, K. E. \& Dickerson, G. E. (1952). Res. Bull. Mo. agric. Exp. Sta. no. 493.

Hansen Larsen, L., Clausen, H. \& Jespersen, J. [1952]. Breeding and Feeding of Cattle and Pigs. (Published on the occasion of the VIth International Congress of Animal Husbandry, Copenhagen, Denmark, 1952).

Hanson, L. E. (1954). Feed Age, 4, no. 3, p. 20.

Heinemann, W. W., Ensminger, M. E., Cunha, T. J. \& McCulloch, E. C. (1946). 7. Nutr. 3 I, 107.

Heitman, H. Jr. \& Hughes, E. H. (1949). F. Anim. Sci. 8, I71.

Leitch, I. \& Godden, W. (1941). Tech. Commun. Bur. Anim. Nutr., Aberd., no. 14.

Mitchell, H. H. \& Kelley, M. A. R. (1938). F. agric. Res. 56, 81 I.

Nelson, L. F., Hazel, L. N., Moore, A. A., Maddock, H. M., Ashton, G. C., Culbertson, C. C. \& Catron, D. V. (1953). Iowa Fm Sci. 7, no. 8, p. 3 .

Steffen, H. (1954). Fm Ë Home Sci., Utah, 14, 78.

Wood, T. B. (1926). \%. agric. Sci. 16, 425 .

\section{Factors Affecting the Efficiency of Food Conversion in Poultry}

\section{By W. Bolton, Poultry Research Centre, King's Buildings, West Mains Road, Edinburgh 9}

Experiments on the efficiency of food conversion by poultry can be subjected to several criticisms. First, the assessment of food intake has not been sufficiently detailed. Most workers have used gross food consumption, thereby ignoring the relative digestibilities of the ingredients; others have used gross digestible nutrients but have based their digestibility values on the tables published by Woodman 
(1939) and Morrison (1936), although these tables relate to ruminants and not necessarily to poultry. Quite often even the meal mixture was not given. Where egg weights were given, in only one instance (Greenwood \& Bolton, 1954) has an attempt been made to partition them into total weights of yolk, albumen and shell, yet yolk is far richer in energy than is albumen. The level of production achieved influences the efficiency of utilization, as illustrated by the results given in Table $\mathrm{I}$. In growth trials, although it has been known for some time that efficiency of food

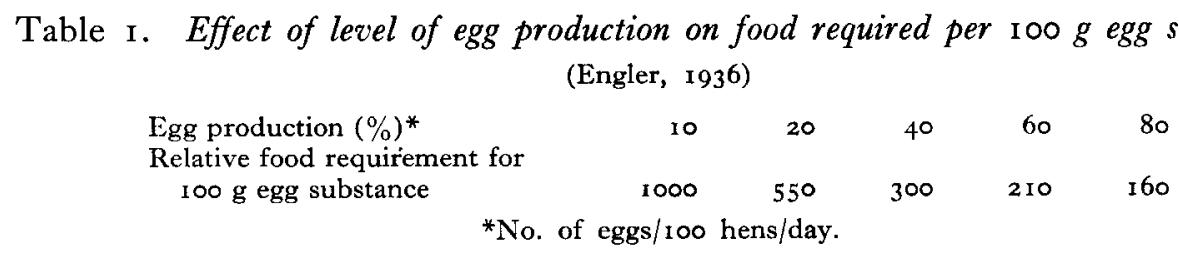

conversion decreases with increasing weight, most trials have compared birds of equal ages instead of equal weights.

\section{Egg production}

General trend of production during life. Egg production begins from zero in late summer or early autumn, slowly increases to a peak in the spring and then falls off towards the end of the Ist laying year (Pearl \& Surface, I9I I C Coles \& Shrimpton, I95 I). This trend also applies to I-year-old hens (Hervey, I924). It has been shown (Bird \& Sinclair, 1938-9) that once the bird has reached its mature weight, the amount of food required both for maintenance and for the production of a unit weight of egg is relatively constant. The efficiency of food conversion to eggs will therefore follow the curve for egg production.

As a bird grows older its annual egg production, and hence its efficiency of food conversion, declines. The average annual drop in production has been estimated as $12 \%$ (Brody, Henderson \& Kempster, 1923-4; Hall \& Marble, 1931) and 19\% (Clark, I940).

Gross energetic efficiency of egg production. The gross energetic efficiency has been variously estimated at somewhere between 8 and $27 \%$ (see Table 2 ). In the most critical experiment (Greenwood \& Bolton, 1954), not only were the actual digestible nutrients determined in the food given, but the weights of yolk and albumen produced were estimated. It was found that, when subjected to normal seasonal changes, the gross energetic efficiency over the I 5 months' experimental period was $24.6 \%$; the maintenance of comparable birds in a constant environment of $65^{\circ} \mathrm{F}$, relative humidity $60 \%$, $12 \mathrm{~h} \mathrm{light/day} \mathrm{and} \mathrm{air} \mathrm{movement} \mathrm{force} \circ$ Beaufort increased egg production by $30 \%$ and the gross energetic efficiency to $31.9 \%$, an increase in gross energetic efficiency of $23 \%$.

The gross amount of food necessary to produce a $2 \mathrm{oz}$. egg has been estimated at between $40 \mathrm{~g}$ and $64 \mathrm{~g}$ (Titus, I 928-9; Joshi, Shaffner \& Jull, I 949; Byerly, I 94 I). The (U.S.A.) National Research Council: Committee on Animal Nutrition (1950) 
Table 2. Estimates by different workers of gross energetic efficiency of egg production

\begin{tabular}{|c|c|c|}
\hline Author & No. of eggs/year & $\begin{array}{c}\text { Gross } \\
\text { energetic efficiency } \\
(\%)\end{array}$ \\
\hline \multirow[t]{2}{*}{$\begin{array}{l}\text { I eitch \& Godden (I 94I) } \\
\text { (medium heavy) }\end{array}$} & $\begin{array}{l}120 \\
200\end{array}$ & $\begin{array}{r}7.9 \\
11.8\end{array}$ \\
\hline & $3^{6} 5$ & $17 \cdot 7$ \\
\hline \multirow{5}{*}{$\begin{array}{l}\text { Brody, Funk \& Kempster (1938) } \\
\quad \text { (Leghorns) }\end{array}$} & 100 & I I $\cdot 0$ \\
\hline & 150 & 14.0 \\
\hline & 200 & 17.0 \\
\hline & 250 & $20 \cdot 0$ \\
\hline & 360 & $27 \cdot 0$ \\
\hline Alder (1934) & 208 & 17.0 \\
\hline Waite (I934) & I 18 & $11 \cdot 2$ \\
\hline (Leghorns) & 256 & 18.9 \\
\hline Bennett (1939) & 202 & $12 \cdot 6$ \\
\hline (Leghorn $\times$ Rhode Island Red) & I 96 & 13.0 \\
\hline \multicolumn{3}{|l|}{ Heywang (I940) } \\
\hline Average weight: $1910 \mathrm{~g}$ & 146 & $13 \cdot 6$ \\
\hline $157 \circ \mathrm{g}$ & I 7 I & $17 \cdot 6$ \\
\hline $1760 \mathrm{~g}$ & I93 & $17 \cdot 2$ \\
\hline
\end{tabular}

in footnotes to Tables 10 and I s suggest $40 \mathrm{~g}$ food/egg, and in Table 7 the authors appear to adopt the basis of $63.5 \mathrm{~g}$ food/2 oz. egg. The bibliography at the end of the report does not list any publications on food efficiency and it is somewhat difficult to determine how the authors arrived at these two values.

Net energetic efficiency. The food eaten by a bird can be apportioned to its three major uses; maintenance, egg production and gain in weight:

Food $=\mathrm{A}+\mathrm{B} \times($ egg mass $)+\mathrm{C} \times($ live weight $)+\mathrm{D} \times($ change in weight $)$, where $A, B, C$ and $D$ are constants.

Some workers (Joshi et al. I949; Bird \& Sinclair, 1938-9) have used body-weight as such in their calculations, others (Brody, Funk \& Kempster, I 938) have used its 0.73 rd power. The results obtained indicate that slightly under I $\mathrm{g}$ food is required per $g$ egg.

Effect of food restriction. The maintenance requirement has first call on the food eaten, hence any restriction in food intake should be reflected in decreased egg production.

Heywang (1940) found that rationing a bird to $87.5 \%$ of normal intake reduced egg production by $30 \%$, and a $75 \%$ ration gave a decrease of $50 \%$. Rationing can also be effected with similar results by increasing the proportion of indigestible material in the diet (Bird \& Whitson, 1946; Heuser, Norris, Peeler \& Scott, 1945). The gross food intake was maintained constant when ground oats were compared with potato meal (Bolton \& Hale, r 945) and it was found that the birds receiving potato meal laid $20 \%$ more eggs than those given ground oats, owing probably to the higher content of absorbable food in the diet.

Effect of light. The first suggestion that a bird's sex cycle was related to the annual variation in the hours of sunlight was made nearly 50 years ago (Schafer, 1907). Since then it has been found (Dougherty, I922; Gutteridge, Bird, MacGregor \& Pratt, 1944-5; Nicholas, Callenbach \& Murphy, 1944) that increase in the daily light period stimulates the fowl's reproductive system so that it is possible to 
promote a high rate of egg production in winter by supplementing natural daylight with artificial light; that this stimulation is also evident in birds that have not finished moulting (Riley \& Byerly, 1943), and that the increased egg production is accompanied by increased food efficiency (Rhys \& Parkhurst, 1931; Kennard \& Chamberlin, I931; Payne \& Simmons, 1934; Callenbach, Nicholas \& Murphy, 1943).

Birds reared with access to sunshine laid more eggs than those not receiving sunshine (Buckner, Martin \& Insko, 1933) but $24 \mathrm{~h}$ light daily from hatching onwards decreased egg production in the pullet year (Callenbach et al. 1944).

The least daily light period for maximal production seems to be $13 \mathrm{~h}$ (Dobie, Carver \& Roberts, I946; Byerly \& Moore, 194I; Whetham, 1933); an intensity of I ft. c. is adequate and the colour of the light is not important. Byerly (I948) has propounded the following equation to relate period of light and rate of egg production:

Rate of egg production $=\mathrm{A}+\mathrm{B} \log \mathrm{L}+\mathrm{C} \Sigma \mathrm{T}+\mathrm{DN}$, where $\mathrm{A}, \mathrm{B}, \mathrm{C}$ and $\mathrm{D}$ are constants, $\mathrm{L}$ is the daily light period in $\mathrm{h}, \mathrm{T}$ is the time in months since first egg and $\mathrm{N}$ is the daily dark period. For maximal egg production $\mathrm{L}$ was equal to $\mathrm{I} 4$ and $\mathrm{N}$ to 10.

Benoit, Grangaud \& Sarfati (194I) have suggested that light acts indirectly upon the reproductive organs, according to Benoit (1935) by first stimulating the pituitary; Ivanova (1935) is of the opinion that it can act through the skin, since she observed testicular growth in sparrows with the heads covered and plucked skin exposed to light. Ivanova's view was given support by an experiment in which daylight was augmented by dim red lights. Although the lighted birds did not leave their perches any earlier and hence did not have greater opportunities for feeding, egg production increased by $46 \%$ (Platt, 1953).

In another experiment (Temperton \& Dudley, 1947) though extra lighting had no effect on egg production, the rate decreased when the lights were discontinued in March, but not if they were used until May.

The use of ultraviolet light of $2538 \AA$ increased egg production up to $14 \%$ (Barott, Schoenleber \& Campbell, 1950), but heat had no effect (Lee, Hamilton, Henry \& Callanan, 1937, 1939; Gutteridge et al. 1944-5), although it has been reported that temperatures below $\circ^{\circ}$ and over $23^{\circ}$ reduced egg production (Hays, 1932).

Effect of date of hatching on sexual maturity and egg production. Numerous workers (Buss, I919; Kempster \& Henderson, I922; Hays \& Bennett, I923; Hays \& Sanborn, 1926; Berry \& Walker, I927; Knox, 1930; Byerly \& Knox, 1946; Davidson, McCrary $\&$ Card, 1946) have shown that early-hatched pullets mature earlier and lay more eggs than late-hatched pullets. Those hatched in April laid the largest number of eggs in the pullet year and those hatched in November the smallest (Jeffrey \& Platt, 194I).

When pullets were hatched at I $_{5}$-day intervals those hatched in spring or early summer matured more quickly than those hatched in autumn or winter (Upp \& Thompson, 1927), and the range of age of maturity was less with autumn-hatched birds (Greenwood \& Blyth, 1946). 
Irrespective of hatching date, early-maturing pullets lay the largest number of eggs (Jull, 1924; Hays, 195 I, I952), and a mathematical relationship between weight at 6 months and egg production in the pullet year has been derived (Hammond \& Haynes, 1944) although variability was too great to permit it to be used for forecasting egg production.

Effect of other factors. It has been shown (Atwood, 192I-2, I922) that birds fed on a poor diet from day-old mature later and lay fewer eggs than birds on normal diets.

In one experiment intensive rearing reduced the age at sexual maturity below that in normal rearing, and when the two lots of mature birds were placed on the same layer's diet the intensively reared birds laid more eggs (Prentice, Baskett \& Robertson, 1930). In other experiments (Bearse, Berg, \& Miller, 1950; Temperton $\&$ Dudley, 1944b; Fronda \& Cruz, 195I) there was no difference, indicating that some saving in food can be effected during the rearing period without prejudice to future egg production.

Treatment of immature pullets with stilbene reduced the age at sexual maturity from 146 to I I 4 days and increased egg production during the pullet year (Schönberg $\&$ Ghoneim, 1946), and the removal of the comb and wattles from immature birds also increased egg production during the pullet year (Temperton \& Dudley, I944a; Nordio, 1951).

The administration of desiccated thyroid to aged hens (Crew, 1925) evoked a marked rejuvenation in appearance and an increase in egg production, and egg production has also been increased by the incorporation of a small amount of iodinated casein in the diet (Turner, Irwin \& Reineke, I945).

Prolonged feeding of antibiotics to laying birds has been reported to increase egg production (Elam, Jacobs \& Couch, I953; Carlson, Wilcox, Kohlmeyer \& Jones, I953) but Sunde, Halpin \& Cravens (1952) and Berg, Carver, Bearse \& McGinnis (1952) found no such effect.

Summary. The foregoing discussion suggests that, to obtain maximal egg production and hence maximal efficiency of food conversion, only pullets hatched in early summer should be used. A small saving in food can be effected by rearing them on a ration of about $90 \%$ of the ad lib. food consumption from 8 weeks to 5 months old. Combs and wattles should be removed before sexual maturity, the length of the lighted part of the day should not be less than $13 \mathrm{~h}$, and the food supply during the laying year must not be restricted, either by rationing or by the inclusion of large quantities of indigestible material in the diet.

\section{Meat production}

General. The curve relating food consumption to live-weight gain has been expressed mathematically (Jull \& Titus, I928; Titus, 1927-8; Titus \& Hendricks, 1930; Hendricks, Jull \& Titus, 1932; Hammond, Hendricks \& Titus, 1938; McCartney \& Jull, 1948; Hess \& Jull, I948) and with birds fed ad lib. on a normal diet the gain of live weight for successive units of food eaten was approximately 0.9 of that for the previous unit. Males were more efficient converters of food to live weight than were females (Brooks, I933; Carver \& Hougan, 1935; Titus, Jull \& 
Hendricks, 1934; Funk, 1943; Hess \& Jull, 1948), either because of their lower maintenance requirement or of a more rapid decrease in efficiency in females due to their lower mature body-weight (Hess \& Jull, I948).

The net efficiency can be derived from the formula

$$
\mathrm{E}=\mathrm{C}-\mathrm{kW} \text {, }
$$

where $\mathrm{E}=$ gain in live weight during period $\div$ food eaten during this period, $\mathrm{C}=$ theoretical maximal efficiency if no food was required for maintenance, $\mathrm{k}=$ maintenance requirement per unit of live weight and $\mathrm{W}=$ live weight.

Net efficiency is constant for a given diet (Hendricks et al. 1932; Titus et al. 1934) and the latter authors found that the predicted live weight was closer to that observed when birds were rationed to $70 \%$ of the ad lib. intake than when they were fed ad lib. When the crude-protein content was increased from 21 to $25 \%$ the $70 \%$ ration was more efficient for growth to $\mathrm{I} \cdot 5 \mathrm{~kg}$ live weight than was the ad lib. diet (Hammond et al. 1938).

During growth the gross efficiency of utilization is a straight-line function of the live weight (Hankins \& Titus, I939; Hammond \& Marsden, 1939; Fox \& Bohren, I952).

Yield of edible meat. Chemical and physical analyses of birds at 8, 12, 16 and 20 weeks old have shown that the ratio of breast to leg to residual meat varied during growth; the percentages of breast and leg decreased and that of residual meat increased (Harshaw, 1938). In the meat itself the water content decreased, while the protein, fat and ash contents, and the ratio of edible meat to bone increased (Hankins \& Titus, 1939). This means that comparative trials should be carried out by rearing birds to the same weight and not, as is so frequently done, to the same age.

The yield of edible meat has been estimated at $50-63 \%$ of the live weight by Brown \& Bean (1952), Broadbent \& Bean (1952) and McNally \& Spicknall (1949) and by calculation from the results of Stotts \& Darrow (1953), Jaap, Renard \& Buckingham (1950) and McNally \& Spicknall (1949).

The difference between 50 and $63 \%$ may be due to the different workers using birds at different stages of maturity.

Effect of environment. Most rapid growth was obtained when the temperature in the brooder fell uniformly from $80^{\circ} \mathrm{F}$ on the 18 th day to $66^{\circ} \mathrm{F}$ on the 3 2nd (Barott $\&$ Pringle, 1950). High temperatures retarded the growth rate (Asmundson \& Lloyd, 1936; Kempster, 1938), and the growth rate was greatest with birds hatched early in the year, fell to a minimum with those hatched in May or June and rose again with those hatched in the autumn (Galpin, I939).

Better growth resulted when $6 \mathrm{~h}$ light alternated with $6 \mathrm{~h}$ darkness than when I $2 \mathrm{~h}$ periods were used (Clegg \& Sanford, 195I), and the growth rate was maximal when $\mathrm{I}$ h light was followed by 3 or $4 \mathrm{~h}$ darkness (Barott \& Pringle, I95I), although neither the colour nor the intensity of the light was important provided that the latter exceeded I ft. c., and the source could be either visible light or ultraviolet light of $2587 \AA$. Extra light does not necessarily evoke an increased growth rate, since in one experiment (Paulino, r949) $4 \mathrm{~h}$ of extra light gave worse results for 
both growth and food efficiency than daylight alone. When birds were reared with daylight or with continuous light and food available from 8 a.m. to 8 p.m. or with continuous light and food available from 8 p.m. to 8 a.m.; both the rate of growth and the efficiency of food conversion were greatest when the birds were fed in the cooler part of the day (Heywang, 1946).

Effect of caponization and hormone treatment. Although caponization reduced losses due to fighting among the males, it did not increase the growth rate above that of intact males (Titus \& Jull, I928; Annin \& Halpin, I938). The implantation of oestrogen pellets under the skin increased the profit margin for turkey toms but not hens (Baum, Walkup, Stadelman \& Faris, 1952) and increased the efficiency of food utilization (Lorenz, 1945) in one experiment but reduced it in another (Gassner \& Wilgus, I948).

The addition of small amounts of thiouracil to the diet has been reported to increase the efficiency of food conversion (Andrews \& Bohren, 1947; Mixner, Tower \& Upp, 1946) and to decrease it (Quisenberry \& Krueger, 1948). Additions of iodinated protein (Protomone, Cerophyl Laboratories Inc.) increased it according to Quisenberry \& Krueger (I948), although others (Ackerson, Borchers, Temper \& Mussehl, I950) could not detect any difference when iodocasein was added to the food.

Effect of vitamin deficiencies. A deficiency of almost any vitamin results in reduced growth rate and efficiency of food conversion. Poultry synthesize ascorbic acid both in the embryonic stage (Suzuki, 1938, I939; Ray, 1934) and later (Plimmer, Rosedale \& Raymond, 1923; Hauge \& Carrick, 1925-6). However, an increase in growth has been reported when ascorbic acid was injected into day-old chicks (Reid, 1950).

Growth-promoting substances. When the residues from the manufacture of antibiotics were added to chick diets a stimulation in growth was observed (Stokstad, Jukes, Pierce, Page \& Franklin, 1949; Stokstad \& Jukes, 1950; Berg, Bearse, McGinnis \& Miller, 1950; Almquist \& Merritt, 1953) but increased efficiency in food conversion was seen only when a small amount of animal protein was present in the diet (Branion \& Hill, 195 I). Trials with the same unsupplemented and supplemented diets in new and old buildings led to the suggestion that this increase in growth rate and efficiency was due to the antibiotic overcoming some growth-depressing infection present in the old houses (Coates, Dickinson, Harrison, Kon, Cummins \& Cuthbertson, 1951; Coates, Dickinson, Harrison, Kon, Porter, Cummins \& Cuthbertson, 1952).

Cuprisulpharsenite (Tangl, I942) and 3-nitro-4-hydroxyphenylarsonic acid (Morehouse \& Mayfield, 1946) possess growth-stimulating properties and the inclusion of the latter in chick diets increased the efficiency of food utilization (Morehouse, 1949).

Surface-active agents (Ely, I95I, I952a-d) have also been reported to stimulate growth and increase the efficiency of food utilization, although contrary opinions have been expressed (Scott, Johnson \& Goffi, 1952).

Summary. The efficiency of conversion of food to meat is highest with males hatched from eggs laid early in the year. Caponization or hormone treatment is 
useful to prevent losses due to fighting. Since the net efficiency of food conversion is constant, food should not be rationed and should be highly digestible. The ideal lighting conditions are I h light followed by 3 or $4 \mathrm{~h}$ darkness, but $6 \mathrm{~h}$ light followed by $6 \mathrm{~h}$ darkness is easier to regulate by time switches. The inclusion of growth-promoting substances in the diet, though not always effective, would probably be beneficial.

\section{REFERENCES}

Ackerson, C.'W., Borchers, R. L., Temper, J. E. \& Mussehl, F. E. (1950). Poult. Sci. 29, 640.

Alder, B. (1934). Bull. Utah agric. Exp. Sta. no. 248 (quoted by Leitch \& Godden, I94I).

Almquist, H. J. \& Merritt, J. B. (1953). Poult. Sci. 32, 878 .

Andrews, F. N. \& Bohren, B. B. (1947). Poult. Sci. 26, 447.

Annin, G. E. \& Halpin, J. G. (1938). Poult. Sci. 17, 4 I9.

Asmundson, V. S. \& Lloyd, W. E. (1936). Poult. Sci. 15, I 86.

Atwood, H. (1921-2). Poult. Sci. I, 177.

Atwood, H. (1922). Bull. W. Va agric. Exp. Sta. no. 179.

Barott, H. G. \& Pringle, E. M. (1950). F. Nutr. 41, 25.

Barott, H. G. \& Pringle, E. M. (195I). F. Nutr. 45, 265.

Barott, H. G., Schoenleber, L. \& Campbell, L. E. (1950). Poult. Sci. 29, 747.

Baum, E. L., Walkup, H. G., Stadelman, W. J. \& Faris, J. E. (1952). Poult. Sci. 31, 723.

Bearse, G. E., Berg, L. R. \& Miller, V. L. (1950). Poult. Sci. 29, $74^{8}$.

Bennett, J. (1939). Harper Adams Util. Poult. F. 24, 35 I.

Benoit, J. (I935). C.R. Soc. Biol., Paris, 120, 133.

Benoit, J., Grangaud, R. \& Sarfati, S. (1941). Bull. Histol. Tech. micr. 18, 173.

Berg, L. R., Bearse, G. E., McGinnis, J. \& Miller, V. L. (1950). Poult. Sci. 29, 629.

Berg, L. R., Carver, J. S., Bearse, G. E. \& McGinnis, J. (1952). Bull. Wash. St. agric. Exp. Sta. no. 534 .

Berry, L. N. \& Walker, A. L., (1927). Bull. N. Mex. agric. Exp. Sta. no. ${ }_{5} 8$.

Bird, H. R. \& Whitson, D. (1946). Poult. Sci. 25, 210.

Bird, S. \& Sinclair, J. W. (1938-9). Sci. Agric. 19, 542.

Bolton, W. \& Hale, R. W. (I945). F. agric. Sci. 35, I 58 .

Branion, H. D. \& Hill, D. C. (195I). Poult. Sci. 30, 793.

Broadbent, M. \& Bean, H. W. (1952). Poult. Sci. 31, 447.

Brody, S., Funk, E. M. \& Kempster, H. L. (1938). Res, Bull. Mo. agric. Exp. Sta. no. 278.

Brody, S., Henderson, E. W. \& Kempster, H. L. (1923-4). F. gen. Physiol. 6, 41.

Brooks, F. D. (1933). Poult. Sci. 12, 299.

Brown, P. B. \& Bean, H. W. (1952). Poult. Sci. 3r, 232.

Buckner, G. D., Martin, J. H. \& Insko, W. M. Jr. (1933). Poult. Sci. 12, 334.

Buss, W. J. (г 19). Mon. Bull. Ohio agric. Exp. Sta. 4, 79.

Byerly, T. C. (1941). Bull. Md agric. Exp. Sta. no. A I (quoted by Joshi, Shaffner \& Jull, I949).

Byerly, T. C. (1948), Poult. Sci. 27, 656 .

Byerly, T. C. \& Knox, C. W. (1946). Poult. Sci. 25, 587.

Byerly, T. C. \& Moore, O. K. (I94I). Poult. Sci. 20, 387.

Callenbach, E. W., Nicholas, J. E. \& Murphy, R. R. (1943). Bull. Pa agric. Exp. Sta. no. 455.

Callenbach, E. W., Nicholas, J. E. \& Murphy, R. R. (1944). Bull. Pa agric. Exp. Sta. no. 461.

Carlson, C. W., Wilcox, R. A., Kohlmeyer, W. \& Jones, D. G. (1953). Poult. Sci. 32, i 76.

Carver, J. S. \& Hougan, M. (1935). Poult. Sci. 14, I18.

Clark, T. B. (1940). Poult. Sci. 19,6r.

Clegg, R. E. \& Sanford, P. E. (1951). Poult. Sci. 3o, 760 .

Coates, M. E., Dickinson, C. D., Harrison, G. F., Kon, S. K., Cummins, S. H. \& Cuthbertson, W. F. J. (1951). Nature, Lond., 168, 332.

Coates, M. E., Dickinson, C. D., Harrison, G. F., Kon, S. K., Porter, J. W. G., Cummins, S. H. \& Cuthbertson, W. F. J. (1952). F. Sci. Fd Agric. 3, 43.

Coles, R. \& Shrimpton, E. A. G. (195I). Agriculture, 58, 28.

Crew, F. A. E. (1925). Proc. roy. Soc. Edinb. 45, 252.

Davidson, J. A., McCrary, C. M. \& Card, C. G. (1946). Quart. Bull. Mich. agric. Exp. Sta. 28, 28 I.

Dobie, J. B., Carver, J. S. \& Roberts, J. (1946). Bull. Wash. agric. Exp. Sta. no. 47ı.

Dougherty, J. E. (1922). Circ. Calif. agric. Exp. Sta. no. 254.

Elam, J. F., Jacobs, R. L. \& Couch, J. R. (1953). Poult. Sci. 32, 792. 
Ely, C. M. (I951). Science, $\mathbf{x 4}, 523$.

Ely, C. M. (1952a). Feedstuffs, 24, 24. Quoted in Biol. Abstr. 1952, 26, 25262.

Ely, C. M. (1952b). Feedstuffs, 24, 26. Quoted in Biol. Abstr. 1952, 26, 25262.

Ely, C. M. (1952c). Feedstuffs, 24, 28. Quoted in Biol. Abstr. 1952, 26, 25262.

Ely, C. M. (1952d). Feedstuffs, 24, 46. Quoted in Biol. Abstr. 1952, 26, 25262.

Engler, H. (1936). World's Poult. Congr. vi. Berlin and Leipzig, p. 249.

Fox, T. W. \& Bohren, B. B. (1952). Poult. Sci. 31, 9 I6.

Fronda, F. M. \& Cruz, I. M. (1951). Philipp. Agric. 35, 9o.

Funk, E. M. (1943). Poult. Sci. 22, 3.

Galpin, N. (1939). Emp. F. exp. Agric. 7, I39.

Gassner, F. X. \& Wilgus, H. S. (1948). Poult. Sci. 27, 663.

Greenwood, A. W. \& Bolton, W. (I954). Unpublished results.

Greenwood, A. W. \& Blyth, J. S. S. (1946). Poult. Sci. 25, 597.

Gutteridge, H, S., Bird, S., MacGregor, H. I. \& Pratt, J. M. (1944-5). Sci. Agric. 25, 3 I.

Hall, G. D. \& Marble, D. R. (1931). Poult. Sci. ro, 194.

Hammond, J. C. \& Haynes, S. K. (I944). Poult. Sci. 23, 355.

Hammond, J. C., Hendricks, W. A. \& Titus, H. W. (1938). F. agric. Res, 56, 791.

Hammond, J. C. \& Marsden, S. J. (1939). Poult. Sci. 18, ir.

Hankins, O. G., \& Titus, H. W. (1939). Yearb. U.S. Dep. Agric. p. 450.

Harshaw, H. M. (1938). Poult. Sci. 17, 163.

Hauge, S. M. \& Carrick, C. W. (1925-6). Poult. Sci. 5, 166.

Hays, F. A. (1932). Bull. Mass. agric, Exp. Sta. no. 289.

Hays, F. A. (I951). Poult: Sci. 30, 723.

Hays, F. A. (1952). Poult. Sci. 3r, ro5o.

Hays, F. A. \& Bennett, J. S. (1923). Poult. Sci. 2, 205.

Hays, F. A. \& Sanborn, R. (1926). Tech. Bull. Mass. agric. Exp. Sta. no. 8.

Hendricks, W. A., Jull, M. A. \& Titus, H. W. (1932). Poult. Sci. r1, 74.

Hervey, G. W. (1924). Bull. N. F. agric. Exp. Sta. no. 402.

Hess, C. W. \& Jull, M. A. (1948). Poult. Sci. 27, 24.

Heuser, G. F., Norris, L. C., Peeler, H. T., \& Scott, M. L. (1945). Poult. Sci. 24, 142.

Heywang, B. W. (r940). Poult. Sci. r9, 29.

Heywang, B. W. (1946). Poult. Sci. 25, 492.

Ivanova, S. (1935). Arch. exp. Path. Pharmak. 179, 349.

Jaap, R. G., Renard, M. M. \& Buckingham, R. D. (1950). Poult. Sci. 29, 874.

Jeffrey, F. P. \& Platt, C. S. (1941). Bull. N. F. agric. Exp. Sta. no. 697.

Joshi, B. C., Shaffner, C. S. \& Jull, M. A. (r949). Poult. Sci. 28, 30r.

Jull, M. A. (1924). Poult. Sci. 3, 153.

Jull, M. A. \& Titus, H. W. (1928). F. agric. Res. 36, 54 r.

Kempster, H. L. (1938). Poult. Sci. 17, 259.

Kempster, H. L. \& Henderson, E. W. (1922). Bull. Mo. agric. Exp. Sta. no. I97.

Kennard, D. C. \& Chamberlin, V. D. (I93I). Bull. Ohio agric. Exp. Sta. no. 476.

Knox, C. W. (1930). Res. Bull. Iowa agric. Exp. Sta. no. 1 28.

Lee, C. E., Hamilton, S. W., Henry, C. L. \& Callanan, M. E. (1937). Poult. Sci. 16, 267.

Lee, C. E., Hamilton, S. W., Henry, C. L. \& Callanan, M. E. (1939). Poult. Sci. r8, 359.

Leitch, I. \& Godden, W. (1941). Tech. Commun. Bur. Anim. Nutr., Aberd., no. I4.

Lorenz, F. W. (1945). Poult. Sci. 24, 91.

McCartney, M. G. \& Jull, M. A. (1948), Poult. Sci. 27, 17.

McNally, E. H. \& Spicknall, N. H. (1949). Poult. Sci. 28, 562.

Mixner, J. P., Tower, B. A. \& Upp, C. W. (1946). Poult. Sci. 25, 536.

Morehouse, N. F. (1949). Poult. Sci. 28, 375.

Morehouse, N. F. \& Mayfield, O. J. (I946). F. Parasit. 32, 20.

Morrison, F. B. (1936). Feeds and Feeding. Ithaca, New York: Morrison Publishing Co.

National Research Council: Committee on Animal Nutrition (1950). Recommended Nutrient Allowances for Poultry. Washington, D.C.: National Research Council.

Nicholas, J. E., Callenbach, E. W. \& Murphy, R. R. (1944). Bull. Penn. agric. Exp. Sta. no. 462.

Nordio, C. B. (I95 I). Boll. Soc. ital. Biol. sper. 27, 368.

Paulino, L. A. (1949). Philipp. Agric. 33, 63.

Payne, L. F. \& Simmons, L. J. (1934). Poult, Sci. 13, 323.

Pearl, R. \& Surface, F. M. (191 I). Bull. U.S. Dep. Agric. no. I Io.

Platt, C. S. (1953). Poult. Sci. 32, 143.

Plimmer, R. H. A., Rosedale, J. L. \& Raymond, W. H. (1923). Biochem. F. 17, 787.

Prentice, I. H., Baskett, R. G., \& Robertson, G. S. (I930). World's Poult. Congr. Iv. London. Sect. B, p. 242 . 
Quisenberry, J. H. \& Krueger, W. F. (1948). Poult. Sci. 27, 681.

Ray, S. N. (1934). Biochem. F. 28, 189.

Reid, M. E. (1950). Fed. Proc. 9, 368.

Rhys, I. W. \& Parkhurst, R. T. (1932). Bull. nat. Inst. Poult. Husb. no. 6.

Riley, G. M. \& Byerly, T. C. (1943). Poult. Sci. 22, 301.

Schafer, E. A. (1907). Nature, Lond., 77, I59.

Schönberg, A. \& Ghoneim, A. (1946). Nature, Lond., 157, 77.

Scott, H. M., Johnson, B. C. \& Goffi, E. A. (I952). Poult. Sci. 31, 746.

Stokstad, E. L. R. \& Jukes, 'T. H. (1950). Poult. Sci. 29, 6 I .

Stokstad, E. L. R., Jukes, T. H., Pierce, J. V., Page, A. C. Jr. \& Franklin, A. L. (I949). J. biol. Chem. r8o, 647 .

Stotts, C. E. \& Darrow, M. I. (1953). Poult. Sci. 32, 145.

Sunde, M. L., Halpin, J. G. \& Cravens, W. W. (i952). Poult. Sci. 3I, 6 I7.

Suzuki, S. (1938). F. orient. Med. 29, 36.

Suzuki, S. (1939). F. orient. Med. 3o, 282 .

Tangl, H. (1942). Arch. exp. Path. Pharmak. 199, 561.

Temperton, H. \& Dudley, J. F. (1944a). Harper Adams Util. Poult. F. 29, 7.

Temperton, H. \& Dudley, J. F. (1944b). Harper Adams Util. Poult. F. 29, 19.

Temperton, H. \& Dudley, J. F. (1947). Harper Adams Util. Poult. F. 32, 35.

Titus, H. W. (1 927-8). Poult. Sci. 7, 254.

Titus, H. W. (1 928-9). Poult. Sci. 8, 80.

Titus, H. W. \& Hendricks, W. A. (1930). World's Poult. Congr. Iv. London. Sect. B, p. 285.

Titus, H. W. \& Jull, M. A. (1928). F. agric. Res. 36, 5 I 5 .

Titus, H. W., Jull, M. A. \& Hendricks, W. A. (1934). Y. agric. Res. 48, $8 \mathrm{I} 7$.

Turner, C. W., Irwin, M. R. \& Reineke, E. P. (1945). Poult. Sci. 24, I7I.

Upp, C. W. \& Thompson, R. B. (1927). Bull. Okla. agric. Exp. Sta. no. 167.

Waite, R. H. (1934). Bull. Md agric. Exp. Sta. no. 359. (quoted by Leitch \& Godden, 1941).

Whetham, E. O. (1933). F. agric. Sci. 23, 383 .

Woodman, H. E. (1939). Bull. Minist. Agric., Lond., no. $4^{8}$. 